Research Article

Fatma Bibi*, Iftikhar Ahmad, Allah Bakhsh, Sidra Kiran, Subhan Danish, Hameed Ullah, Asif-ur-Rehman

\title{
Effect of Foliar Application of Boron with Calcium and Potassium on Quality and Yield of Mango cv. Summer Bahisht (SB) Chaunsa
}

https://doi.org/10.1515/opag-2019-0009

received September 8, 2018; accepted January 6, 2019

\begin{abstract}
Poor uptake of nutrients not only deteriorates the quality but also the yield of horticultural crops. Among various macro and micronutrients, the role of $\mathrm{K}, \mathrm{Ca}$ and $B$ is very important. Therefore, balanced application and uptake of $\mathrm{K}$ and $\mathrm{Ca}$ and $\mathrm{B}$ can improve the quality and yield of mango trees. So, a field study was conducted with the hypothesis that combined application of $\mathrm{K}$ and $\mathrm{Ca}$ along with $\mathrm{B}$ would be effective to improve yield and quality of Mango cv. Summer Bahisht (SB) Chaunsa. There were two sources of $\mathrm{Ca}\left(\mathrm{CaCl}_{2}\right.$ and $\left.\mathrm{Ca}\left(\mathrm{NO}_{3}\right)_{2}\right)$ and three sources of $\mathrm{K}\left(\mathrm{KNO}_{3}, \mathrm{~K}_{2} \mathrm{SO}_{4}\right.$ and $\mathrm{K}$-Citrate) combined with boric acid (BA). All Ca and $\mathrm{K}$ sources were applied at the rate of $1 \%$ while BA was applied at $0.2 \%$. As compared to control, a significant improvement in fruit set panicle ${ }^{-1}(35.7 \%$ and $50.0 \%$ ), fruit retention (125\% and $40 \%)$, shelf life $(73.3 \%$ and $36.6 \%$ ), total soluble solids (35.1\% and $40.6 \%)$ and fruit yield (52.5\% and 49.2\%) in 2016 and 2017 respectively, confirmed the effectiveness of $\mathrm{KNO}_{3}(1.0 \%)+\mathrm{BA}(0.2 \%)$. Between $\mathrm{CaCl}_{2}$ and $\mathrm{Ca}\left(\mathrm{NO}_{3}\right)_{2}$, application of $\mathrm{Ca}\left(\mathrm{NO}_{3}\right)_{2}$ was found more efficacious regarding improvement of quality and yield of SB Chaunsa. It is concluded that to improve the quality and yield of Mango cv. SB Chaunsa, $\mathrm{KNO}_{3}$ $(1.0 \%)+\mathrm{BA}(0.2 \%)$ is the best nutrients combination, and $\mathrm{Ca}\left(\mathrm{NO}_{3}\right)_{2}$ is a better option as compared to $\mathrm{CaCl}_{2}$.
\end{abstract}

Keywords: SB Chaunsa, Foliar application, Nutrients, Quality, Yield

\footnotetext{
*Corresponding author: Fatma Bibi, Mango Research Institute, Multan, Punjab, Pakistan, E-mail: fatima.bibi71@gmail.com Iftikhar Ahmad, Allah Bakhsh, Sidra Kiran, Asif-ur-Rehman, Mango Research Institute, Multan, Punjab, Pakistan Hameed Ullah, Horticultural Research Station, Noushera District Khushab, Punjab, Pakistan

Subhan Danish, Department of Soil Science, Faculty of Agricultural Sciences and Technology, Bahauddin Zakariya University, Multan, Punjab, Pakistan
}

\section{Introduction}

Horticultural crops are seriously impacted by climatic variables (Normand et al. 2015). Due to changing climatic conditions, tropic and sub-tropic areas of the world are facing many challenges regarding mango productivity (Gerbaud 2012; Normand et al.2015). Every stage of mango phenological cycle (flowering, fruit growth, harvest/ vegetative growth and vegetative growth/rest) may get influenced by a change in temperature, precipitation, light, humidity and greenhouse gases (Christensen et al. 2007). The anticipated climate changes and increasing $\mathrm{CO}_{2}$ levels with global warming can result in greater changes in mango flowering and ultimately low yields of mangoes. Erratic flowering in mango, due to changes in the climate, especially high temperature during the flowering season, have been reported (Bhagwan et al. 2011). To obtain higher yields, it is the necessity of time to improve nutrient supply and fertilizer use efficiency to minimize emissions of greenhouse gases. Due to high temperature in summers, mango gets vigorous vegetative growth and in winter early flowering issue becomes the reason for low yield (Normand et al. 2009). Increasing fertilizer application will increase mangoes yield but will not halt the decline in flowering or fruit drop, which is directly influenced by climatic factors. High temperature, low soil moisture and high evaporative demand cause reduction in mango yield (Schaffer et al. 2009). So, under changing climate, the management of natural resources like nutrients and water are a possible solution to the upcoming menace.

Potassium (K) is involved in quality-related characteristics of fruit and is called a quality element (Ahmad et al. 2018). It is crucial for many biochemical reactions that are essential for enzyme activation and physiological processes in cell (Anees et al. 2016). These reactions play a major role in ion transport between cells and stomatal conductance under different climatic variables (temperature, light, humidity), thus affect 
fruit quality (Eisenacha and Angeli 2017). Fruit size, appearance, color, soluble solids, acidity, vitamin content, taste, as well as shelf-life are significantly influenced by an adequate supply of $\mathrm{K}$ (Tohidloo et al. 2018). To trigger flowering in mango potassium nitrate is being applied generally by mango growing farmers to enhance productivity. It increases the tolerance of plants for many stresses: drought, excessive water, salt stress, high and low-temperature stresses (Dutta 2011; Eliwa 2003). Application of additional potassium via foliar spray or nutrient solution has been shown to improve many growth and fruit biochemical characteristics in crops such as strawberry, olives and passion fruit (Gurung et al. 2014; Zivdar et al., 2016; Tohidloo et al., 2018). Mandal et al. (2012) also reported that pre-harvest sprays of potassium and growth regulators applied in the integrated fruit production systems, improve fruit quality in winter guava. Foliar spray of aqueous solutions of potassium nitrate can induce flowering in certain varieties of mango (Sergent et al. 2000).

Similarly, calcium $(\mathrm{Ca})$ is very important in controlling fruit disorders. In Pakistani soils, deficiency of $\mathrm{Ca}$ is low due to calcic parent material of soil. The problem in plants may be due to poor distribution after uptake (Marschner 2011). To get mangoes with longer shelf life in extreme temperatures of summer, a pre-harvest spray of Ca can also be effective. In fruits many disorders are relevant to B deficiency, even when B is in ample supply, suggesting these disorders are physiological in nature and related to the mobility of B in the plant tissues (Tohidloo and Souri, 2009). Besides disorders, fruit setting and retention percentage of fruit are attributed to B concentration in fruit (Dell and Huang 1997). It is documented fact that less bioavailability of B in floral structure, resulted in low fruit setting from flowers and their retention percentage on panicle. Muengkaew et al. (2016) reported the effects of $\mathrm{Ca}$ and $\mathrm{B}$ on pollen germination and fruit set in mango cv. Mahachanok. Their investigations showed a significant positive effect on pollen germination and fruit setting with co-application of $\mathrm{Ca}$ and $\mathrm{B}$ at $3.0 \mathrm{ml} / \mathrm{L}$. With application of $\mathrm{K}, \mathrm{Ca}$ and $\mathrm{B}$ efficient increase in fruit set and fruit retention, as well as fruit quality characteristics of mango is expected. Therefore, the current study was designed with the objective to examine the effects of foliar application of boric acid alone and in combination with various sources and $\mathrm{Ca}$ and $\mathrm{K}$ on yield and quality of mango cv. Summer Bahisht (SB) Chaunsa in changing climate conditions.

\section{Materials and Methods}

\subsection{Experimental site}

A two-year study was conducted in the orchard of Mango Research Institute, Multan, Pakistan ( $30^{\circ} 09^{\prime} \mathrm{N}, 71^{\circ} 26^{\prime} \mathrm{E}$; elevation $410 \mathrm{~m}$ ), during the years 2015-2017. Randomly distributed 20-25 years old healthy trees of mango cv. SB Chaunsa were selected. The experiment started in August by application of macronutrients after fruit harvest (July 2015).

\subsection{Experiment layout}

The experiment was comprised of 7 treatments and 4 replications following a randomized complete block design. Treatment combinations were set as: Control $\left(\mathrm{T}_{1}\right)$, Boric Acid $(0.2 \%)\left(\mathrm{T}_{2}\right), \mathrm{Ca}\left(\mathrm{NO}_{3}\right)_{2}(1.0 \%)+$ Boric Acid $(0.2 \%)$ $\left(\mathrm{T}_{3}\right), \mathrm{CaCl}_{2}(1.0 \%)+$ Boric Acid $(0.2 \%)\left(\mathrm{T}_{4}\right)$, K-Citrate $(1.0 \%)$ + Boric Acid (0.2\%) $\left(\mathrm{T}_{5}\right), \mathrm{K}_{2} \mathrm{SO}_{4}(1.0 \%)+$ Boric Acid (0.2\%) $\left(\mathrm{T}_{6}\right)$ and $\mathrm{KNO}_{3}(1.0 \%)+$ Boric Acid $(0.2 \%)\left(\mathrm{T}_{7}\right)$. The N-P-K were applied according to Mango Research Institute (MRI) Multan recommendations at the rate of (1.5-1-1) kg/plant/ year respectively, to all experimental trees according to their time schedule. All the P $(1000 \mathrm{~g})$ and one half of $\mathrm{N}$ (750g) and K (500g) were applied after fruit harvest (end of July) according to annual fertilizer program of MRI Multan, and the other half $\mathrm{N}$ and $\mathrm{K}$ were applied before flowering ( $1^{\text {st }}$ week of February) as suggested by Iftikhar et al. (2018). The fertilizer sources used were: Urea, single super phosphate (SSP), and sulphate of potash (SOP). During November soil and leaf sampling was carried out. All the recommended management practices (irrigation, hoeing, and pesticide and herbicide applications (when needed) were carried out throughout the year. The treatments were applied combined at pre-flowering during the month of March and pre-harvest stage ( $1^{\text {st }}$ week of June) of fruit with the help of tractor-mounted Jecto Sprayer.

\subsection{Meteorological data of experimental site}

Meteorological data were collected from the Central Cotton Research Institute, Multan (three km towards south-west), during the study years (2015-2017). Mean monthly high and low air temperature $(\stackrel{\circ}{\circ})$, relative humidity $(\%)$, average of rainfall $(\mathrm{mm})$ was recorded during the study years (20152017). The mean annual minimum and maximum air temperatures were $21.86^{\circ} \mathrm{C}$ and $39.95^{\circ} \mathrm{C}$, respectively, with 
a mean annual precipitation of $59 \mathrm{~mm}$ and $75 \%$ humidity (Figure 1).

\subsection{Basic Analysis of Soil samples}

Composite soil samples were taken during the month of November under the canopy area of selected trees. Soil samples were air dried then ground. Soil pHs was measured with pH meter ( $\mathrm{pH} 200$, Lovibond, SensoDirect) from saturated soil paste. Electrical conductivity (ECe) was determined from soil paste extract with NEOMET EC-400L EC meter. The extractable $\mathrm{P}$ and $\mathrm{B}$ were determined with spectrophotometer (T60 UV visible PG Instrument) while extractable $\mathrm{K}$ with flame photometer (Digiflame 2000), respectively. The textural class of soil was determined by using the Bouyoucos method, while the organic matter content was determined by following Ryan et al. (2001).

\subsection{Tissue Analysis}

During two years of experimentation 6-7 months old ( $5^{\text {th }}$ leaf of the branch) leaf samples from all directions of each tree before the $2^{\text {nd }}$ week of November were collected. Samples were oven dried until constant weight at $70^{\circ} \mathrm{C}$ then ground in a Wiley Micro Mill to pass through a 40-mesh screen, and stored in labelled plastic bags. N, P, K and B concentration in leaf samples were estimated following the standard procedures and protocols. Leaf sample $(0.5$ g) was digested in tri-acid mixture i.e. sulphuric acid, nitric acid, perchloric acid (5:2:1) (Rashid 1986) and run with spectrophotometer-T60 UV visible PG Instrument (metavanadate yellow color method) for P (Jackson 1962; Jones et al. 1991) and B (Azomethane-H + Buffer) (Gaines and Mitchell 1979), flame photometer (Digiflame 2000) for $\mathrm{K}$ (Jones et al. 1991), respectively. For the determination of $\mathrm{N}$, digestion was done with sulphuric acid and catalyst

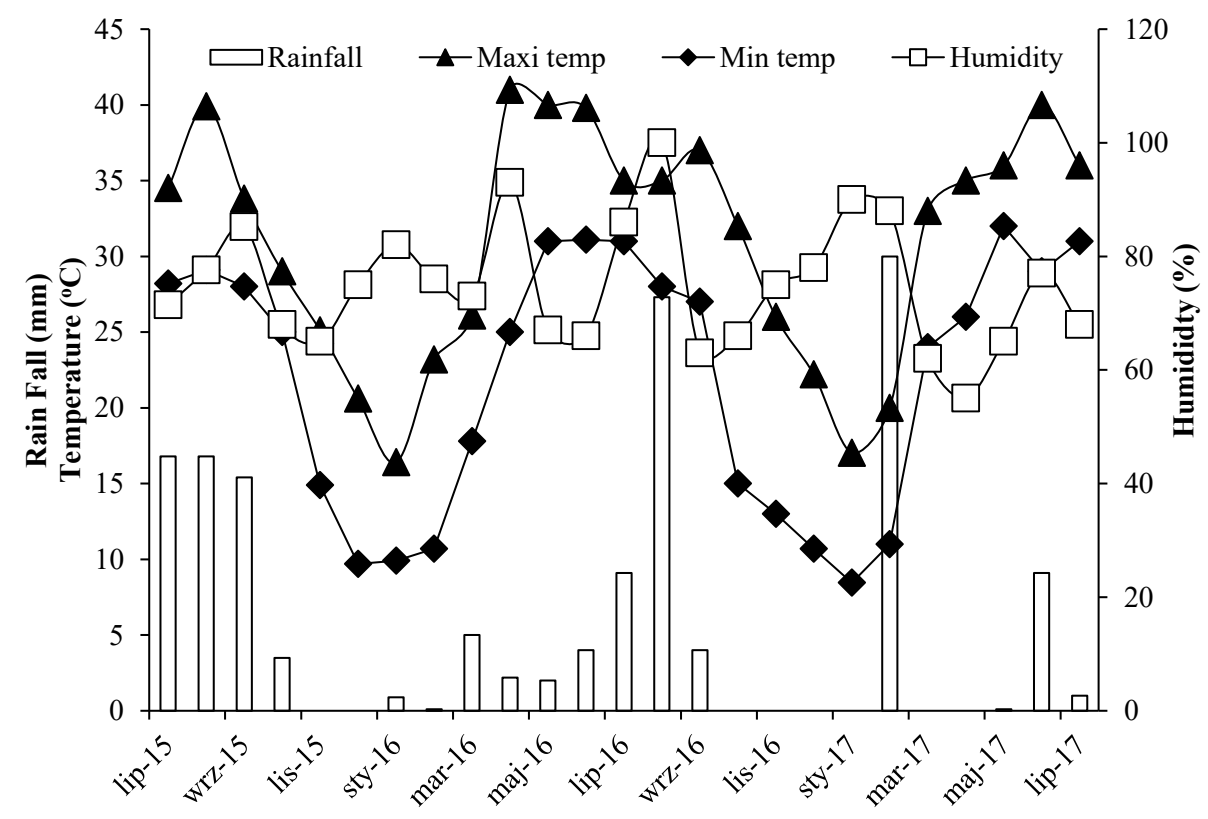

Figure 1. Meteorological data of 2016 and 2017

Table 1. Characteristics of experimental soil before treatments application

\begin{tabular}{lllllllll}
\hline Year Wise & Soil depth & $\mathrm{pH}_{\mathrm{s}}$ & $\mathrm{EC}_{\mathrm{e}}$ & Soil O.M & Ava.P & Ext. K & Ext. Boron & Texture \\
\cline { 2 - 8 } & $\mathbf{( c m )}$ & - & (dS m-1) & $\mathbf{( \% )}$ & (mg kg-1) & (mg kg-1) & (mg kg-1) & - \\
\hline $\mathbf{2 0 1 5 - 1 6}$ & $\mathbf{0 - 1 5}$ & 8.18 & 2.67 & 0.54 & 7.56 & 170 & 0.66 & Loam \\
& $\mathbf{1 5 - 3 0}$ & 8.10 & 2.32 & 0.43 & 4.30 & 165 & 0.55 & 0.56 \\
$\mathbf{2 0 1 6 - 1 7}$ & $\mathbf{0 - 1 5}$ & 8.45 & 2.96 & 0.56 & 7.52 & 175 & 175 & 0.53 \\
& $\mathbf{1 5 - 3 0}$ & 8.34 & 2.90 & 0.45 & 4.20 & 175 \\
\hline
\end{tabular}


mixture of $\mathrm{K}_{2} \mathrm{SO}_{4}$-Se (100:1) while distillation was done on Kjeldahl's (UDK132 semi-automatic) method (Jackson 1958).

Fruit Retention: The area of $1.0 \mathrm{~m}^{2}$ from all four sides of the tree was marked for determination of fruit retention (\%) i.e. from mustard stage to the marble stage of fruit, retention was assessed. After each month, data was recorded by adopting the standard protocol, for three months.

Yield (kg/tree): Every year at the time of fruit harvest four mangoes from each plant were harvested from the marked area and average yield was calculated by multiplying the average weight of each tree fruit with an average number of fruits.

Fruit weight (g): A top-loading sensitive balance was used for measuring fruit weight after harvest and before ripening in grams $(\mathrm{g})$.

Fruit Volume (cm3): fruit volume was measured in water using a $200 \mathrm{ml}$ plastic jug by water displacement method.

Titratable Acidity: Titratable acidity was measured as \% citric acid of fresh mango juice by titrating the sample to $\mathrm{pH} 8.2$ with $0.1 \mathrm{~N}$ sodium hydroxide $(\mathrm{NaOH})$ as described by Ranganna (1979).

$$
\begin{aligned}
& \text { Acidity }(\%)= {[\text { Volume of } 0.1 \mathrm{~N} \mathrm{NaOH}(\mathrm{mL}) \times 0.067 / \text { Volume }} \\
&\text { of juice }(\mathrm{mL})] \times 100
\end{aligned}
$$

Total Soluble Solids (TSS): For total soluble solids (Brix॰) of fresh mango juice, Medline Scientific Ltd digital hand refractometer model SELECT045 was used. In each fruit, $20 \mathrm{~g}$ pulp was collected and homogenized in $80 \mathrm{ml}$ distilled water for 60 seconds. After that, a disposable pipette was used to transfer $1 \mathrm{ml}$ of homogenate on refractometer for measurement of TSS.

Statistical Analysis: Statistical analysis of the obtained data of all the parameters was performed using the analysis of variance (ANOVA) on computer-designed software Statistix ${ }^{\circledR} 8.1$ version. The difference among treatment means was compared by Tukey's test at $\mathrm{p} \leq 0.05$.

Ethical approval: The conducted research is not related to either human or animal use.

\section{Results and Discussion}

\subsection{Number of fruit set panicle-1 and fruit retention}

Effect of foliar application of variable sources of $\mathrm{Ca}$ and $\mathrm{K}$ with $\mathrm{B}$ remained significant for number of fruit set panicle ${ }^{-1}$ and fruit retention. It was observed that application of $\mathrm{T} 7$ and $\mathrm{T} 6$ were statistically similar but remained significant as compared to control for number of fruit set panicle ${ }^{-1}$ in 2016 (Table 2). Application of T3 was significantly different as compared to $\mathrm{T} 4$ for number of fruit set panicle ${ }^{-1}$ in 2016. Treatments $\mathrm{T} 2$ and control were statistically similar for number of fruit set panicle ${ }^{-1}$ in 2016. In 2017, all the treatments were significant but in T7 number of fruit set panicle ${ }^{-1}$ remained significantly higher among all amendments as compared control for (Table 2). Maximum increase of $35.7 \%$ and $50.0 \%$ in number of fruit set panicle ${ }^{-1}$ was noted as compared to control in 2016 and 2017 respectively where T7 was applied. Application of T7 differed significantly as compared to control for fruit retention in 2016. Among Ca sources, application of T3 remained significant as compared to $\mathrm{T} 4$ for fruit retention in 2016. It was observed that control, $\mathrm{T} 2$ and $\mathrm{T} 4$ remained statistically similar to each other for fruit retention in 2016 (Table 2). In 2017 both T6 and T7 remained statistically similar to each other but differed significantly as compared to control for fruit retention. However, the application of T4, T3, T2 and control remained non-significant in 2017 for fruit retention (Table 2). Maximum increase of $125 \%$ and $40 \%$ in fruit retention was noted as compared to control in 2016 and 2017 respectively where T7 was applied. The reduction in fruit drop with the application of treatments as compared to control might be due to B, could cause an increase in auxin production in fruit petiole or inhibition of ethylene production (Malik and Singh 2006). Whereas, the role of $\mathrm{K}$ in reducing fruit drop is expected due to its catalytic effect in many biochemical reactions occurring in physiological processes of the plant (Baiea et al. 2015; Dutta 2011; Eliwa 2003). Yeshitela et al. (2005) argued that better availability of $\mathrm{NO}_{3}^{-1}$ plays important role in the improvement of number of panicles in mango cultivated in Ethopia. The improvement in fruit set panicles ${ }^{-1}$ in current experiment might be also due to better availability of nitrate ion where $\mathrm{Ca}\left(\mathrm{NO}_{3}\right)_{2}$ was applied as compared to $\mathrm{CaCl}_{2}$. 
Table 2. Effects of foliar application of variable sources of $\mathrm{Ca}$ and $\mathrm{K}$ with Boric acid on number of fruit set panicle $\mathrm{e}^{-1}$ and fruit retention of SB Chaunsa

\begin{tabular}{|c|c|c|c|c|}
\hline \multirow[t]{3}{*}{ Treatments } & 2016 & 2017 & 2016 & 2017 \\
\hline & \multicolumn{2}{|c|}{ Number of fruit set panicle-1 } & \multicolumn{2}{|l|}{ Fruit retention } \\
\hline & - & & (\%) & \\
\hline T1 (Control) & $28 \pm 0.29^{e}$ & $28 \pm 0.41^{g}$ & $0.39 \pm 0.014^{\mathrm{e}}$ & $0.40 \pm 0.018^{c}$ \\
\hline $\mathrm{T} 2$ & $30 \pm 0.25$ de & $31 \pm 1.80^{\mathrm{e}}$ & $0.42 \pm 0.013^{\mathrm{de}}$ & $0.41 \pm 0.019^{c}$ \\
\hline $\mathrm{T} 3$ & $35 \pm 1.08^{b c}$ & $35 \pm 2.17^{d}$ & $0.54 \pm 0.034^{c}$ & $0.43 \pm 0.027^{c}$ \\
\hline $\mathrm{T} 4$ & $31 \pm 0.48^{d}$ & $30 \pm 0.65^{f}$ & $0.43 \pm 0.007 \mathrm{de}$ & $0.41 \pm 0.007^{c}$ \\
\hline T5 & $33 \pm 0.25^{\mathrm{cd}}$ & $37 \pm 2.04^{c}$ & $0.48 \pm 0.013^{d}$ & $0.46 \pm 0.025^{b c}$ \\
\hline T6 & $37 \pm 1.22$ ab & $40 \pm 1.85^{b}$ & $0.64 \pm 0.062^{b}$ & $0.52 \pm 0.021^{\mathrm{ab}}$ \\
\hline T7 & $38 \pm 0.25^{a}$ & $42 \pm 0.85^{a}$ & $0.88 \pm 0.032^{\mathrm{a}}$ & $0.56 \pm 0.023^{a}$ \\
\hline
\end{tabular}

Different letters showed statistical difference at $p \leq 0.05$.

Table 3. Effects of foliar application of variable sources of $\mathrm{Ca}$ and $\mathrm{K}$ with Boric acid on shelf life, acidity of juice and total soluble solids of SB Chaunsa fruit

\begin{tabular}{lcccccc}
\hline Treatments & 2016 & 2017 & 2016 & 2017 & 2016 & 2017 \\
\cline { 2 - 7 } & \multicolumn{2}{c}{ Shelf Life } & \multicolumn{2}{c}{ Acidity of Juice } & \multicolumn{2}{c}{ Total Soluble Solids } \\
\cline { 2 - 7 } & \multicolumn{2}{c}{ Days } & \multicolumn{2}{c}{ (\%) } & \multicolumn{2}{c}{ Brix } \\
\hline T1 (Control) & $7.50 \pm 0.29^{\mathrm{e}}$ & $9.00 \pm 0.41^{\mathrm{d}}$ & $0.29 \pm 0.007^{\mathrm{a}}$ & $0.27 \pm 0.009^{\mathrm{a}}$ & $17.1 \pm 1.14^{\mathrm{b}}$ & $17.7 \pm 0.54^{\mathrm{c}}$ \\
T2 & $9.00 \pm 0.41^{\mathrm{c}-\mathrm{e}}$ & $10.0 \pm 0.41^{\mathrm{cd}}$ & $0.26 \pm 0.005^{\mathrm{ab}}$ & $0.25 \pm 0.011^{\mathrm{ab}}$ & $18.9 \pm 0.39^{\mathrm{ab}}$ & $19.1 \pm 0.36^{\mathrm{c}}$ \\
T3 & $10.8 \pm 0.25^{\mathrm{bc}}$ & $11.8 \pm 0.48^{\mathrm{a}-\mathrm{c}}$ & $0.21 \pm 0.008^{\mathrm{cd}}$ & $0.22 \pm 0.010^{\mathrm{ab}}$ & $21.4 \pm 0.43^{\mathrm{ab}}$ & $22.1 \pm 0.57^{\mathrm{ab}}$ \\
T4 & $8.50 \pm 0.29^{\mathrm{de}}$ & $10.3 \pm 0.48^{\mathrm{b}-\mathrm{d}}$ & $0.26 \pm 0.006^{\mathrm{b}}$ & $0.25 \pm 0.013^{\mathrm{ab}}$ & $19.9 \pm 0.69^{\mathrm{ab}}$ & $20.5 \pm 0.50^{\mathrm{bc}}$ \\
T5 & $9.50 \pm 0.29^{\mathrm{cd}}$ & $10.8 \pm 0.25^{\mathrm{b}-\mathrm{d}}$ & $0.24 \pm 0.006^{\mathrm{bc}}$ & $0.23 \pm 0.018^{\mathrm{ab}}$ & $20.4 \pm 1.17^{\mathrm{ab}}$ & $19.4 \pm 0.13^{\mathrm{bc}}$ \\
T6 & $13.0 \pm 0.71^{\mathrm{a}}$ & $13.5 \pm 0.65^{\mathrm{a}}$ & $0.20 \pm 0.006^{\mathrm{d}}$ & $0.22 \pm 0.018^{\mathrm{ab}}$ & $23.1 \pm 1.81^{\mathrm{a}}$ & $24.9 \pm 0.46^{\mathrm{a}}$ \\
T7 & $12.3 \pm 0.48^{\mathrm{ab}}$ & $12.3 \pm 0.63^{\mathrm{ab}}$ & $0.19 \pm 0.004^{\mathrm{d}}$ & $0.20 \pm 0.005^{\mathrm{b}}$ & $22.8 \pm 1.13^{\mathrm{a}}$ & $23.7 \pm 1.32^{\mathrm{a}}$ \\
\hline
\end{tabular}

Different letters showed statistical difference at $\mathrm{p} \leq 0.05$.

Table 4. Effects of foliar application of variable sources of $\mathrm{Ca}$ and $\mathrm{K}$ with Boric acid on N, P, K and B uptake in SB Chaunsa leaves

\begin{tabular}{|c|c|c|c|c|c|c|c|c|}
\hline \multirow[t]{3}{*}{ Treatments } & 2016 & 2017 & 2016 & 2017 & 2016 & 2017 & 2016 & 2017 \\
\hline & \multicolumn{2}{|c|}{ Nitrogen } & \multicolumn{2}{|c|}{ Phosphorus } & \multicolumn{2}{|c|}{ Potassium } & \multicolumn{2}{|c|}{ Boron } \\
\hline & \multicolumn{2}{|c|}{ (\%) } & \multicolumn{2}{|c|}{ (\%) } & \multicolumn{2}{|c|}{ (\%) } & \multicolumn{2}{|c|}{ (mg kg-1) } \\
\hline T1 (Control) & $0.70 \pm 0.04^{d}$ & $0.75 \pm 0.02^{d}$ & $0.08 \pm 0.006^{f}$ & $0.10 \pm 0.005^{\mathrm{e}}$ & $0.38 \pm 0.011$ & $0.40 \pm 0.009^{d}$ & $14.5 \pm 0.13^{\mathrm{e}}$ & $15.42 \pm 0.43^{f}$ \\
\hline T2 & $0.86 \pm 0.02 \mathrm{bc}$ & $0.83 \pm 0.03^{a-c}$ & $0.16 \pm 0.005^{a}$ & $0.17 \pm 0.006^{a}$ & $0.41 \pm 0.006$ & $0.42 \pm 0.005^{\mathrm{cd}}$ & $26.0 \pm 0.20^{a}$ & $26.88 \pm 0.52^{a}$ \\
\hline T3 & $0.98 \pm 0.05^{\mathrm{ab}}$ & $0.85 \pm 0.02^{\mathrm{a}-\mathrm{c}}$ & $0.13 \pm 0.006^{\mathrm{cd}}$ & $0.13 \pm 0.004^{c d}$ & $0.44 \pm 0.011$ & $0.46 \pm 0.014^{b}$ & $23.5 \pm 0.16^{b}$ & $22.93 \pm 0.43^{c}$ \\
\hline T4 & $0.76 \pm 0.03^{c d}$ & $0.78 \pm 0.04^{b c}$ & $0.12 \pm 0.006^{\mathrm{de}}$ & $0.13 \pm 0.006^{d}$ & $0.40 \pm 0.011$ & $0.42 \pm 0.009^{c d}$ & $21.5 \pm 0.34^{c}$ & $19.17 \pm 0.28^{\mathrm{e}}$ \\
\hline T5 & $0.88 \pm 0.05^{b c}$ & $0.89 \pm 0.07^{b c}$ & $0.14 \pm 0.006^{b c}$ & $0.15 \pm 0.006^{b c}$ & $0.46 \pm 0.018$ & $0.44 \pm 0.009 \mathrm{bc}$ & $25.0 \pm 0.12^{\mathrm{a}}$ & $24.60 \pm 0.23^{b}$ \\
\hline T6 & $0.93 \pm 0.04^{\mathrm{ab}}$ & $0.86 \pm 0.04^{\mathrm{a}-\mathrm{c}}$ & $0.10 \pm 0.005^{\mathrm{e}}$ & $0.13 \pm 0.003^{d}$ & $0.45 \pm 0.006$ & $0.47 \pm 0.006^{a b}$ & $20.5 \pm 0.33^{c}$ & $20.63 \pm 0.24^{d}$ \\
\hline T7 & $1.03 \pm 0.04^{\mathrm{a}}$ & $0.90 \pm 0.03^{a}$ & $0.15 \pm 0.004^{a b}$ & $0.16 \pm 0.006^{a b}$ & $0.48 \pm 0.011$ & $0.49 \pm 0.011^{a}$ & $18.8 \pm 0.11^{d}$ & $20.10 \pm 0.19 \mathrm{de}$ \\
\hline
\end{tabular}

Different letters showed statistical difference at $\mathrm{p} \leq 0.05$. 


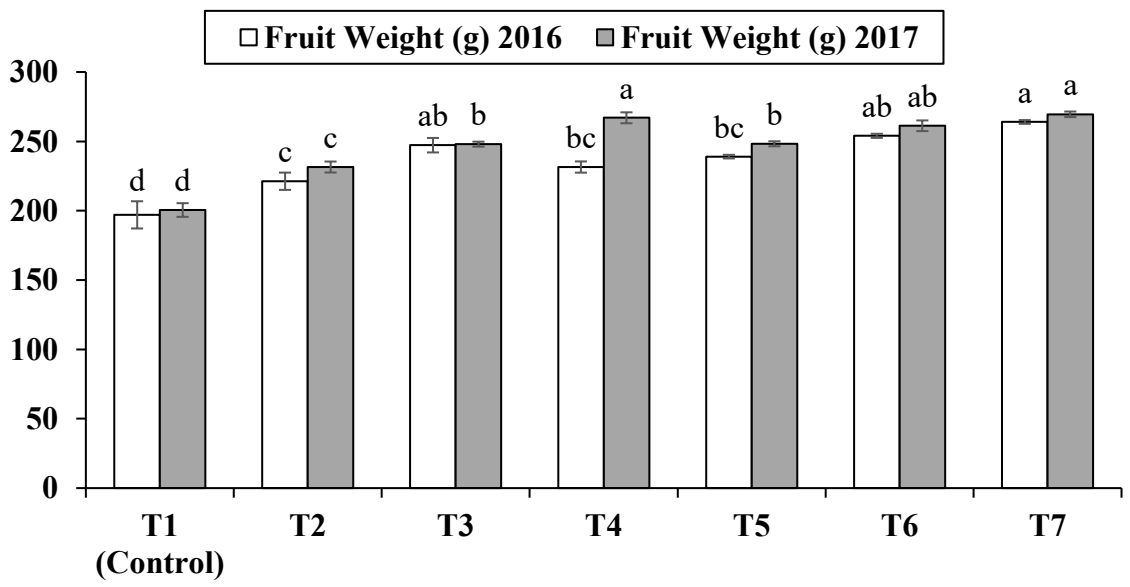

Figure 2. Effects of foliar application of variable sources of $\mathrm{Ca}$ and $\mathrm{K}$ with $\mathrm{B}$ on SB Chaunsa fruit weight

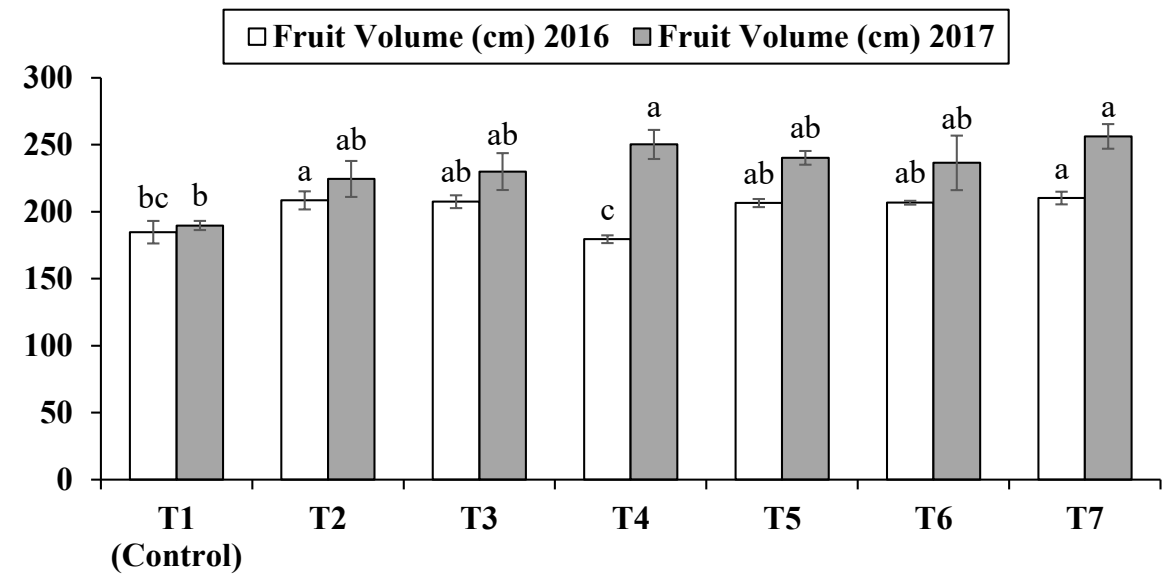

Figure 3. Effects of foliar application of variable sources of $\mathrm{Ca}$ and $\mathrm{K}$ with $\mathrm{B}$ on SB Chaunsa fruit volume

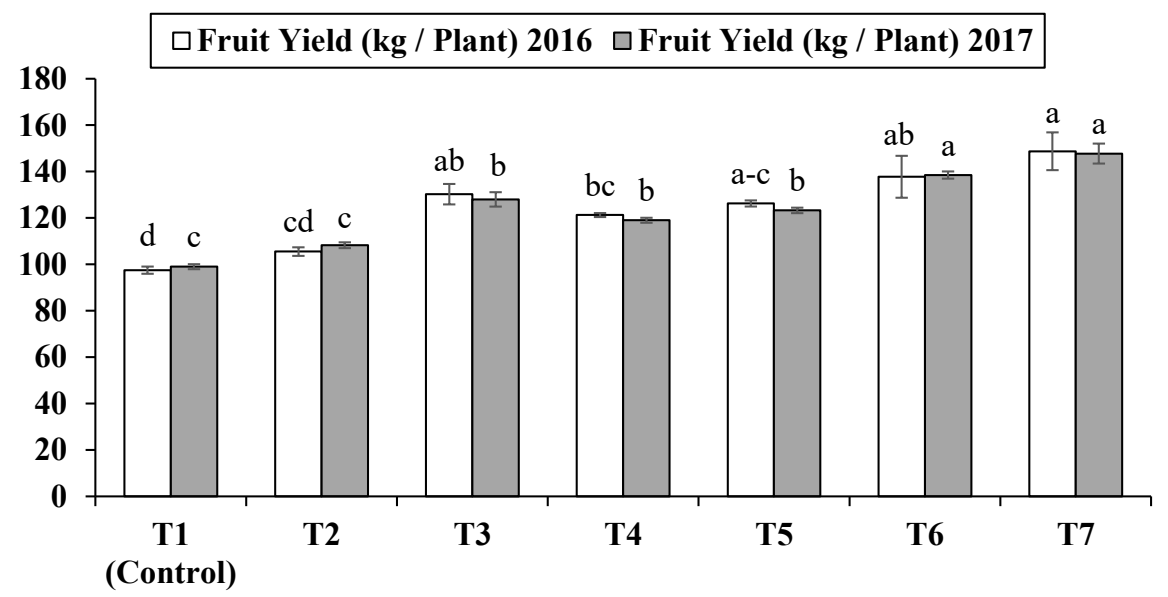

Figure 4. Effects of foliar application of variable sources of Ca and K with B on SB Chaunsa fruit yield / plant 


\subsection{Shelf life, acidity of juice and total soluble solids}

Effect of foliar application of variable sources of $\mathrm{Ca}$ and $\mathrm{K}$ with $\mathrm{B}$ remained significant for shelf life, acidity of juice and total soluble solids. For shelf life, both T7 and T6 remained statistically similar to each other but differ significantly as compared to control in 2016 and 2017. Application of T3 differed significantly as compared to T4 in 2016 but remained statistically similar to each other in 2017 for shelf life. As compared to control, application of T2 remained non-significant for shelf life in 2016 and 2017. Maximum increase of $73.3 \%$ and $36.6 \%$ in shelf life was noted as compared to control where $\mathrm{T} 6$ was applied. Foliar application of variable sources of $\mathrm{Ca}$ and $\mathrm{K}$ with $\mathrm{B}$ remained significant for acidity of juice. It was observed that $\mathrm{T} 6$ and T7 remained significantly different as compared to control for reduction in acidity of juice in 2016. Comparative to T2 and control, application of T3 also differed significantly for acidity of juice in 2016. However, only T7 remained significant as compared to control for reduction in acidity of fruit in 2017. Maximum reduction of $34.4 \%$ and $25.9 \%$ in acidity of juice was noted as compared to control in 2016 and 2017 respectively where T7 was applied. In the case of TSS, T6 and T7 differed significantly as compared to control in 2016 and 2017. Application of T3 remained nonsignificant in 2016 but remained significant in 2017 as compared to control for TSS. Maximum increase of 35.1\% and 40.6 in TSS was noted as compared to control in 2016 and 2017 respectively where T6 was applied. The results are in agreement with the findings of Khan et al. (2009) in aonla. They reported that an increase in fruits quality and shelf life might be due to the better intake of nutrients. According to Khalaj et al. (2016), preharvest spray of B and Ca on Asian pear fruits significantly improved postharvest fruit quality and reduced its browning incidence due to polyphenol oxidase activity. Similar results were obtained by Zivdar et al. (2016) who showed that foliar application of $\mathrm{K}$ during growth period significantly increased physiochemical and postharvest quality of olive, including the oil properties. Strawberry growth and fruit biochemical characteristics including TSS and vitamin $\mathrm{C}$ were significantly improved by higher $\mathrm{K}$ application in nutrient solution, while titrateable acidity and $\mathrm{pH}$ of fruit remain unchanged (Tohidloo et al. 2018). The quality element $\mathrm{K}$ affected the TSS maximum with the application of T7 followed by T6. Dutta (2011) also found improvement in TSS contents in fruit due to $\mathrm{K}$ application. The decline in titratable acidity with the application of $\mathrm{K}$ and boric acid as compared to control is attributed to the application of $\mathrm{K}$. Boron and $\mathrm{K}$ can influence the metabolism of plant tissues (fruits) to reduce the titrateable acidity of fruit. The shift in biochemical reactions toward more sugar production can result in reduction in titrateable acidity content. However, in many cases there may be no effect of fertilization on titrateable acidity or $\mathrm{pH}$ of fruits (Tohidloo et al. 2018).

\subsection{Nutrients in leaves}

Effect of foliar application of variable sources of $\mathrm{Ca}$ and $\mathrm{K}$ with $\mathrm{B}$ remained significant for $\mathrm{N}, \mathrm{P}, \mathrm{K}$ and $\mathrm{B}$ concentration in leaves. For $\mathrm{N}$ concentration in leaves, T3, T6 and T7 remained statistically similar to each other but differed significantly as compared to control in 2016. Application of T4 and control remained statistically similar to each other for leaves N concentration in 2016. However, in 2017 all the treatments remained statistically similar to each other but differed significantly as compared to control for leaves $\mathrm{N}$ concentration. In the case of $\mathrm{P}$ concentration in leaves, all the treatments differed significantly but $\mathrm{T} 2$ and T7 remained significant as compared to control in 2016 and 2017. Application of T6 and T7 differed significantly as compared to control for $\mathrm{K}$ concentration in leaves in 2017. All the treatments remained non-significant for $\mathrm{K}$ concentration in leaves in 2016. For B concentration, $\mathrm{T} 2$ and $\mathrm{T} 5$ remained statistically similar to each other but differed significantly as compared to control for B concentration in leaves in 2016. However, in 2017 all the treatments remained significant but $\mathrm{T} 2$ gave significantly higher B concentration in leaves as compared to control. The results are in line with the findings of other studies, as spraying mango trees with different forms of $\mathrm{K}$ sources improves plant growth and leaf mineral contents (Ebeed and Migeed 2005; Dutta 2011; Razek 2013; Taha 2014). Saykhul et al. (2013) argued that the availability of $\mathrm{K}$ is improved, might be due to better translocation of $\mathrm{K}$ with water uptake under hydroponic conditions. Nutrient management is the largest share to increase crop yield and quality, maintaining soil productivity and sustaining food security. The $\mathrm{K}$ requirement of fruit crops is highest due to its role in the physiological process and fruit quality. To ensure its availability to fruit, leaf contents must be optimum (Ganeshamurthy et al. 2011).

\subsection{Fruit weight and volume}

Effect of foliar application of variable sources of $\mathrm{Ca}$ and $\mathrm{K}$ with $\mathrm{B}$ remained significant for fruit weight and volume. For fruit weight, T3 and T7 were statistically similar to each other but differed significantly best as 
compared to control in 2016. Application of T2, T4 and T5 remained statistically similar to each other but remained significant as compared to control for fruit weight in 2016. It was observed that $\mathrm{T} 7, \mathrm{~T} 6$ and $\mathrm{T} 4$ differed significantly as compared to control for fruit weight in 2017. Application of T3 and T5 did not differ significantly with each other but remained significantly different as compared to control for fruit weight in 2017. Maximum increase of 34\% and 35\% in fruit weight was noted as compared to control in 2016 and 2017 respectively where T7 was applied. Application of T2 and $\mathrm{T} 7$ remained significantly best as compared to control for fruit volume in 2016. However, in 2017, application of T4 and T7 differed significantly as compared to control for fruit volume. Maximum increase of $13.8 \%$ and $35 \%$ in fruit volume was noted as compared to control in 2016 and 2017 respectively where T7 was applied. The results are in accordance with the findings of (Dutta 2011; Baiea et al. 2015).

\subsection{Fruit yield}

Effect of foliar application of variable sources of $\mathrm{Ca}$ and $\mathrm{K}$ with $\mathrm{B}$ remained significant for fruit yield. Application of T3, T5, T6 and T7 remained significant as compared to control and $\mathrm{T} 2$ for fruit yield in 2016. It was observed that T6 and T7 differed significantly among all the treatments for fruit yield in 2017. As compared to T2 and control, the addition of T3 and T5 also gave significantly higher fruit yield in 2017. Maximum increase of $52.5 \%$ and $49.2 \%$ in fruit yield was noted as compared to control in 2016 and 2017 where T7 was applied. This also proves the high demand of fruit trees as compared to other crops. High rate of $\mathrm{K}$ is needed to achieve not only highest total fruit production but also the greatest percentage of fruit production suitable for marketing (Ganeshamurthy et al. 2011). Mango trees have a mild alternate bearing habit. In fruit trees, fruit set and retention are generally a function of plant genetic and management practices including nutrient fertilization (Zivdar et al. 2016). In many trees including mango the intensity of fruit set and/or fruit dropping is greatly influenced by status of phytohormone and sugar levels of plant tissues (Souri and Hatamian 2018). The three nutrients under study (K, Ca, and B) are involved in flower induction and flower initiation leading to a vigorous flowering and fruit set. In some aspects they are interrelated and have close relation with carbohydrates and phytohormones of plant tissues (Souri and Hatamian 2018). It has been shown that $K$ may be a limiting factor for crop production especially in high yielding varieties or in soil with less available K (Zivdar et al. 2016; Tohidloo et al. 2018). In plants, optimum phytoassimilate and sugar production depends on adequate supply of $\mathrm{K}$ and B (Marschner, 2011). Nevertheless, the mechanism of B uptake and its loading into xylem particularly at low B supply is not well known. In plants, both passive and active processes could play role in uptake and translocation of $B$, depending on B concentration in the medium (Tohidloo and Souri 2009). Due to its physiochemical characteristics in soil and in plant cells, continuous supply of B is a prerequisite for optimum plant growth, vigorous flowers, fruits set and fruit quality. In plant, sugar alcohols (sorbitol and manitol) play an important role in the retranslocation of B (Tohidloo and Souri 2009). Therefore, changing the physiological conditions of plant toward higher sugar alcohols production may benefits B uptake and translocation in plants. This confirms our results that application of additional $\mathrm{K}$ may benefit $\mathrm{B}$ uptake and translocation, as the best treatment in the present study was T6 or T7.

\section{Conclusion}

It is concluded that foliar application of $\mathrm{KNO}_{3}(1.0 \%)$ + Boric Acid (0.2\%) and $\mathrm{K}_{2} \mathrm{SO}_{4}(1.0 \%)+$ Boric Acid $(0.2 \%)$ are equally effective and better approach for the improvement in fruit retention, fruit weight, fruit volume, fruit yield plant ${ }^{-1}$, TSS and shelf life under current climatic scenario. However, $\mathrm{KNO}_{3}(1.0 \%)+$ Boric Acid $(0.2 \%)$ is the best treatment for improvement in fruit set panicle ${ }^{-1}$ comparative to all other treatments of the current study.

Conflict of interest: Authors declare no conflict of interest.

\section{References}

Ahmad I., Bibi F., Bakhsh A., Ullah H., Danish S., Asif-ur-Rehman., Assessment of various levels of potassium citrate and sucrose along with boric acid on quality and yield of Sufaid Chaunsa, Intern. J. Biosci., 2018, 13(1), 188-195

Anees M.A., Ali A., Shakoor U., Ahmed F., Hasnain Z., Hussain A., Foliar applied potassium and zinc enhances growth and yield performance of maize under rainfed conditions. Int. J. Agric. Biol., 2016, 18, 1025-1032

Baiea M.H.M., Sharony T.F.E., Eman A.A., Moneim A.E., Effect of different forms of potassium on growth, yield and fruit quality of mango cv. Hindi, Int. J. Chem. Tech. Res., 2015, 8(4), 1582-1587

Bhagwan A., Vanajalatha K., Reddy I.P., Sarkar S.K., Girwani A., Standardization of dosage and time of soil application of cultar on flowering and yield of mango cv. Banganpalli. In: $\mathrm{H}$. Ravishankar, Garg, N., Mishra, M. (Eds.), Global Conference on 
Augmenting Production and Utilization of Mango: Biotic and Abiotic Stresses (held on 21-24th June, Lucknow, India), Uttar Pradesh, Lucknow, 2011, 1, 1-233

Dell B., Huang L., Physiological response of plants to low boron. Plant and soil, 1997, 193, 103-120

Dutta P., Effect of foliar boron application on panicle growth, fruit retention and physico-chemical characters of mango cv. Himsagar. Ind. J. Hort., 2011, 61, 265-266

Ebeed S., Migeed M.M.M.A., Effect of spraying sucrose and some nutrient elements on Fagri Kalan mango trees. J. App. Sci. Res., 2005, 1, 341-346

Eisenacha C., Angeli A. De., Ion Transport at the Vacuole During Stomatal Movements. Plant Physiol., 2017, 174, 520-530

Eliwa G.I., Effect of foliar spray of some micronutrients and Gibberellin on leaf mineral content, fruit set, yield and fruit quality of “Anna” apple trees. Alex. J. Agric. Res., 2003, 48, 137-143

Faust M., Evolution of fruit nutrition during the 20th century. Hort. Sci., 1979, 14(3), 321-325

Gaines T.P., Mitchell G.A., Boron determination in plant tissue by the Azomethine-H method. Commun. Soil Sci. Plant Anal., 1979, 10, 1099-1108

Ganeshamurthy N., Satisha G.C., Patil P., Potassium nutrition on yield and quality of fruit crops with special emphasis on banana and grapes. Karnataka J. Agric. Sci., 2011, 24 (1), 29-38

Gurung,N., Swamy G.S.K., Sarkar S.K., Ubale N.B., Effect of chemicals and growth regulators on germination, vigour and growth of passion fruit (Passiflora edulis Sims). The Bioscan., 2014, 9(1), 155-157

Jackson M.L., Soil Chemical Analysis, Prentice-Hall, Inc, 1962, 183, 219-284

Jackson M.L., Soil Chemical Analysis. Prentice Hall, Englewood Cliffs, NewJersey, 1958, 42-47

Jones J.B., Wolf H.B., Mills H.A, Plant Analysis Handbook: A Practical Sampling, Preparation, Analysis, and Interpretation Guide. Micro-Macro Publishing Inc., Athens, GA, USA, 1991

Khalaj K., Ahmadi N., Souri M.K., Improvement of postharvest quality of asian pear fruits by foliar application of boron and calcium. Horticulturae, 2016, 3(1), 15(1-8)

Khan S., Singh H.K., Pratap B., Impact of foliar application of micronutrients and Thiourea on growth, fruit yield and quality of aonla (Emblica officinalis Gaerth) cv. Narendra Aonla-6. Annals Hort., 2009, 2(1), 83-85

Léchaudel M., Vercambre G., Lescourret F., Normand F., Génard $M$., An analysis of elastic and plastic fruit growth of mango in response to various assimilate supplies. Tree Physiol., 2007, $27,219-230$

Léchaudel M., Génard M., Lescourret F., Urban L., Jannoyer M., Modeling effects of weather and source-sink relationships on mango fruit growth. Tree Physiol., 2005a, 25, 583-597

Malik A.U., Singh Z., Improved fruit retention, yield and fruit quality in mango with exogenous application of polyamines. Sci. Hort., 2006, 110, 167-174

Mandal G., Dhaliwal H.S., Mahajan B.V.C., Effect of pre-harvest application of NAA and potassium nitrate on storage quality of winter guava (Psidium guajava). Indian J. Agri. Sci., 2012, 82(11), 985-989

Marschner H., In: Marschner, H. (Ed.), Marschner's Mineral Nutrition of Higher Plants. 3rd edition, Academic Press, 2011
Normand F., Lauri, P.E, Assessing models to predict vegetative growth of mango at the current-year branch scale. Am. J. Bot., 2012, 99(3), 425-437

Normand F., Lauri P.E., Legave J.M., Climate change and its probable impacts on mango production and cultivation. In: Mango: Opportunities and Challenges in the $21^{\text {st }}$ Century. $\mathrm{X}$ International Mango Symposium 3-7 June 2013, Punta Cana, Dominican Republic, 2013

Penter M.G., Stassen P.J.C., The effect of pre- and postharvest calcium applications on the postharvest quality of Pinkerton avocados. South African Avocado Growers' Association, 2000, 23, 1-7

Rashid A., Mapping zinc fertility of soils using indicator plants and soils analysis. PhD Dissertation, University of Hawaii, HI, USA, 1986

Razek A.E., Allah A.S.E., Saleh M.M.S., Foliar spray of some nutrient elements and antioxidants for improving yield and fruit quality of Hindi mango trees. Mid. East J. Sci. Res., 2013, 14(10), 1257-1262

Ryan J., Estefan G., Rashid A., Soil and plant analysis Laboratory Manual. (2nd ed). International Center for Agricultural Research in Dry Areas, Alleppo, Syria, 2001, 18

Saykhul A., Chatzistathis T., Chatzissavvidis C., Koundouras S., Therios I., Dimassi K., Potassium utilization efficiency of three olive cultivars grown in a hydroponic system. Sci. Hort., 2013, $162,55-62$

Schaffer B., Urban L., Lu P., Whiley A.W., Ecophysiology. In: R.E. Litz (ed.), The Mango. Botany, Production and Uses. $2^{\text {nd }}$ edition. CAB, Wallingford, 2009, 170-209

Sergent E., Leal F., Anez M., Potassium thiosulphate, urea and potassium nitrate applications on vegetative and floral growth in mango 'Haden'. Acta Hort., 2000, 509, 653-660

Singh S., Singh A.K., Joshi H.K., Bagle B.G., Dhandar D.G., Storability of ber (Zizyphus mauritiana Lamk) fruit in semi arid-environment. J. Food Sci. Techn., 2008, 45, 65-69

Souri M.K., Hatamian M., Aminochelates in plant nutrition; a review. J. Plant Nutrit., 2018, 41, doi:10.1080/01904167.2018.1549671

Taha R.A., Hassan, H.S.A., Shaaban, E.A., Effect of different potassium fertilizer forms on yield, fruit quality and leaf mineral content of Zebda Mango trees. Mid. East J. Sci. Res., 2014, 21(3), 518-524

Tohidloo G., Souri M.K., Eskandarpour S., Growth and Fruit Biochemical Characteristics of Three Strawberry Genotypes under Different Potassium Concentrations of Nutrient Solution, Open Agri., 2018, 3, 356-362

Tohidloo G., Souri M.K., Uptake and Translocation of Boron in Two Different Tomato (Lycopersicon esculentum Mill) Genotypes. Horti. Environ. \& Biotech., 2009, 50(6), 487-491

Urban L., Roux X.L., Sinoquet H., Jaffuel S., Jannoyer M., A biochemical model of photosynthesis for mango leaves: evidence for an effect of the local source/sink balance on photosynthetic capacity. Tree Physiol., 2003, 23, 289-300

Yeshitela T., Robbertse P.J., Stassen P.J.C., Potassium nitrate and urea sprays affect flowering and yields of 'Tommy Atkins' (Mangifera indica) mango in Ethiopia. South African J. Plant Soil, 2005, 22, 28-32

Zivdar S., Arzani K., Souri M.K., Moallemi N., Seyyednejad S.M., Physiological and biochemical response of olive (Olea europaea L.) cultivars to foliar potassium application. J. Agri. Sci. Technol., 2016, 18, 1897-1908 